\title{
Doğal Afetlerin Zararlarının Finansmanında Kullanılan Afet Öncesi Finansal Araçlar
}

\author{
Ali YAVUZ \\ Süleyman DİKMEN*
}

Öz

Çalışmada insanları fiziksel, sosyolojik ve ekonomik açıdan etkileyen doğal afetlerin finansmanında kullanılan finansal araçların analiz edilmesi amaçlanmıştır. Doğal afetlerle mücadelede hükümetler, afet öncesinde, esnasında ve sonrasında çeşitli mali araçlar kullanmaktadırlar. Çalışmada afet öncesi finansal araçların teorik yapısı incelendikten sonra Japonya, Meksika ve Türkiye'de uygulanan araçlar ve kurumlar irdelenmiştir.

Afet öncesi finansal araçlar; afet rezerv fonu, afet sigortası, afet tahvilleri ve olağanüstü durum kredisinden oluşmaktadır. Finansal araçlar içerisinde en yaygın kullanılanı ve başarılı sonuçlar vereninin afet sigortaları olduğu tespit edilmiştir. Diğer araçların ise afet sigortasını destekleyici konumda bulundukları görülmüştür. Ayrıca doğal afetlerin daha sık meydana geldiği gelişmiş ülkelerde afet öncesi finansal araçların daha etkin kullanıldığı saptanmıştır.

Anahtar kelimeler: Doğal Afetler, Doğal Afet Öncesi Finansal Araçlar, Afet Bütçeleri.

\section{Pre-Disaster Financial Instruments used for the Finance of the Losses from Natural Disasters}

\begin{abstract}
The study aims to analyze financial instruments used for financing natural disaster that affect people physically, sociologically and economically. For the natural disaster management governments utilize various financial instruments before, during and after the disasters. The study examines the analyses of the theoretical structure of ex-ante financial instruments, and then instruments utilized in Japan,

* Doç. Dr., Süleyman Demirel Üniversitesi, İktisadi ve İdari Bilimler Fakültesi, Maliye Bölümü. E-posta: aliyavuz@sdu.edu.tr

** Arş. Gör., Süleyman Demirel Üniversitesi, Sosyal Bilimler Enstitüsü, Maliye Anabilim Dalı. E-posta: suleymandikmen@sdu.edu.tr
\end{abstract}


Mexico and Turkey and finally the institutions.

Ex-ante disaster financial instruments consist of disaster reserve fund, disaster insurance, disaster bills and emergency credits. It is proven that the most commonly used and successful instrument among financial instruments is the disaster insurances. Also, it is seen that other instruments are supportive for the disaster insurances. Besides, it is also proven that ex-ante disaster financial instruments are used more efficiently in developed countries that have frequent disasters.

Keywords: Natural Disasters, Ex-ante Natural Disaster Financial Instruments, Disaster Budgets.

\section{Giriş}

Dünyada hemen hemen her gün bir doğal afet meydana gelmekte ve binlerce insan bu afetlerden etkilenmektedir. Pek çok insan doğal afetler sonucu evsiz kalmakta, psikolojisi bozulmakta, salgınlar sonucu hastalanmakta veyahut yaşamını kaybetmektedir. İnsan nüfusunun artması, sanayileşme ve kentleşme, yaşam standartlarının gelişmesi gibi etkenler doğal afetlerin her yıl daha fazla yaşanmasına neden olmaktadır. İnsan yaşamını bu denli büyük ölçüde etkileyen doğal afetlerin etkisini azaltmak için hükümetler çeşitli kamu politikaları uygulamaktadırlar.

İnsan yaşamı için birer tehdit oluşturan deprem, heyelan, erozyon, kuraklık, kasırga ve çığ gibi pek çok doğa olayı küreselleşmenin etkisiyle sadece meydana geldiği ülkeyi değil; diğer ülkeleri de ekonomik, sosyolojik, psikolojik ve ekolojik açıdan etkilemektedirler. İnsan yaşamını bu denli büyük ölçüde etkileyen doğa olaylarını ifade etmek için doğal tehlike (natural hazard), doğal afet (disaster) ve doğal felaket (catastrophe) gibi kavramlar kullanılmaktadır. Bu kavramlar arasında bir kavram kargaşası söz konusudur ve çoğu zaman birbirlerinin yerine kullanılmaktadırlar.

Doğal tehlike, insanların can ve mal güvenliği için potansiyel bir tehdit oluşturan doğal bir süreç ve olaydır. Süreç ve olayların kendileri birer tehlike değildir; fakat insanların toprağı kullanımı sonucu oluşmaktadır. Afet ise belirli bir alanda sınırlı bir zaman dilimi içerisinde gerçekleşen tehlikeli bir olaydır. Felaket ise daha büyük afetleri ifade etmektedir ve afetin yaralarının sarılmasında daha fazla harcama yapılmasını ve uzun yıllar geçmesini gerektirir (Keller \& DeVecchio, 2012:3). Afetler tehlikelerin sonucunda ortaya çımaktadır. Deprem bir tehlikedir, depremin olması, can ve mal kaybının meydana gelmesi ise afettir, deprem ile birlikte bir tsunaminin oluşması ve sonucunda can ve mal kaybının artması, yaraların sarılmasının uzun yllar gerektirmesi ise felakettir.

Doğal afetin varlığından söz edebilmek için Afetlerin Epidemiyolojisi Araştırma Merkezi (CRED): EM-DAT dört kriter belirlemiştir. Dört kriterden her hangi birisinin varlığı söz konusu ise, bu olay bir doğal afettir. Kriterler şu şekildedir (EM-DAT, 2014a):

- En az 10 insanın ölümü,

- En az 100 insanın etkilenmesi, 
- Olağanüstü hal ilan edilmesi,

- Uluslararası yardım talep edilmesi.

$\mathrm{Bu}$ çalışmada öncelikle doğal afetlerin olumsuz etkilerine değinilecektir. Doğal afet dönemlerinde hükümetlerin nasıl bir politika izleyecekleri tespit edildikten sonra etkin bir doğal afet finansmanının önündeki eksiklikler belirlenecektir. Son olarak doğal afet zararlarının finansmanında kullanılan finansal araçlar incelendikten sonra bir gelişmiş (Japonya) ve iki gelişmekte olan (Türkiye, Meksika) ülkede uygulanan finansal araçlar ve kurumlar irdelenecektir.

\section{Doğal Afetlerin Etkileri}

Doğal afetlerin her biri temelde fiziksel, sosyolojik ve ekonomik olmak üzere üç şekilde insanları ve çevreyi etkilemektedirler. Doğal afetlerin etkilerini OECD, dört ana grup halinde kategorize etmiştir (OECD, 1994:42): a. Ölenler, yaralananlar ve zarar görenler (fiziksel etki), b. Konut, altyapı, tarım ve yaşam hattı sistemleri gibi fiziksel hasarlar (fiziksel etki), c. Mali ve ekonomik sonuçlar (ekonomik etki), d. Parçalanmış aileler, yetimler, elden kaçan eğitim fırsatları, borçluluk, hayatta kalanların yaşadıkları travma gibi sosyal sonuçlar (sosyolojik etki).

Doğal afetlerin fiziksel etkileri; ölümler, yaralanmalar ve mal zararlarıdır. Tablo 1'de de görüldüğü üzere 1980 sonrası toplam 10.882 doğal afet meydana gelmiştir ve bu doğal afetler sonucu 2.540.531 insan ölmüş, 6.129.678 insan ise yaralanmıştır. Ayrıca bu afetler, yaklaşık 2,5 katrilyon zarara yol açmıştır.

Tablo I. 1980-2014 Döneminde Meydana Gelen Doğal Afetlerin Etkileri

\begin{tabular}{cccccc}
\hline Kıta & $\begin{array}{c}\text { Meydana } \\
\text { Gelen Doğal } \\
\text { Afet Sayısı }\end{array}$ & Ölü Sayısı & $\begin{array}{c}\text { Yaralı } \\
\text { Sayısı }\end{array}$ & $\begin{array}{c}\text { Etkilenen İnsan } \\
\text { Sayısı }\end{array}$ & $\begin{array}{c}\text { Toplam Zarar } \\
(\mathbf{1 0 0 0 \$})\end{array}$ \\
\hline Afrika & 2157 & 734.124 & 80.785 & 419.656 .685 & 25.010 .782 \\
$\begin{array}{c}\text { Kuzey ve Güney } \\
\text { Amerika }\end{array}$ & 2618 & 395.229 & 2.678 .770 & 197.051 .717 & 939.767 .941 \\
Asya & 4177 & 1.223 .674 & 3.290 .131 & 5.415 .710 .338 & 1.180 .741 .886 \\
Avrupa & 1463 & 181.682 & 71.001 & 34.782 .093 & 345.039 .757 \\
Okyanusya & 467 & 5.822 & 8.991 & 20.414 .231 & 71.131 .862 \\
Toplam & $\mathbf{1 0 . 8 8 2}$ & $\mathbf{2 . 5 4 0 . 5 3 1}$ & $\mathbf{6 . 1 2 9 . 6 7 8}$ & $\mathbf{6 . 2 2 7 . 0 3 4 . 8 9 5}$ & $\mathbf{2 . 5 6 1 . 6 9 2 . 2 2 8}$ \\
\hline
\end{tabular}

Kaynak: (EM-DAT, 2014c). 
Doğal afetlerde ölen ve yaralananların sayısını net olarak tespit etmek çok mümkün değildir. Pek çok insan kaybolmakta, afet dolayısıyla başka bölgelere taşınmakta ya da devlet kurumları tarafından bilgiler tam kayıt altına alınamamaktadır¹.

Doğal afetlerin diğer fiziksel etkisi ise mal zararlarıdır. Afetler altyapı üzerinde yapısal ve yapısal olmayan hasarlara ve/veya artan altyapı bozukluklarına, aynı zamanda güvenli ortamlarda saklanan kimyasal maddelerin çevreye salımına neden olabilmektedirler (Middelmann, 2007:9).

Psiko-sosyal, sosyo-demografik, sosyo-politik ve sosyo-ekonomik etkilerden oluşan doğal afetlerin sosyal etkileri, afetlerden hemen sonra kendilerini gösterebilecekleri gibi uzun yıllar sonra da ortaya çıkabilir. Bu etkiler kısaca açılanacak olursa; Psiko-sosyal etkiler; kaygı, depresyon ve üzüntü gibi duygusal eylemler ile uyku ve iştah bozuklukları, ritualistik davranışlar ve madde bağımlılı̆̆ gibi davranışsal etkilerdir. Aynı zamanda yorgunluk, sindirim sistemi bozukluğu, yüz hareketlerinde bozukluk gibi psikofizyolojik etkiler ile dikkat eksikliği, konsantrasyon bozukluğu, konfüzyon gibi bilişsel belirtiler de psiko-sosyal etkilerdir (Lindell \& Prater, 2003:178). Sosyo-demografik etkiler; yaş, din, dil, cinsiyet, etnik grup, meslek, eğitim, medeni durum gibi sosyo-demografik özelliklerde meydana gelen etkilerdir. Afetler dolayısıyla pek çok insan bulundukları yerleşim yerinden taşınmak, eğitimlerini yarım bırakmak ve mesleklerini değiştirmek zorunda kalmaktadırlar. Sosyo-politik etkiler; özellikle afet yönetimi ve afetle mücadele konusunda hükümetlerin başarılı olamaması sonucu sosyal aktivizme neden olabilmektedir. Afet dönemlerinde insanlar mağdurdur ve psikolojik açıdan kötü durumdadırlar. $\mathrm{Bu}$ durum da insanlar için bir çatışma ortamı yaratmaktadır (Lindell, 2013:814). Sosyo-ekonomik etkiler; doğrudan ve dolaylı maliyetleri ifade etmektedir. Doğal afetlerin doğrudan maliyetleri, ülkelerin veya bölgelerin alt yapı, bina, stok mallar gibi fiziksel sermayesinde meydana gelen bozulmaları ve hasarları kapsarken; dolaylı maliyetler, doğal afetin mal akışı üzerindeki olumsuz etkisi sebebiyle afetten sonra üretimin yapılamamasından kaynaklanan maliyetlerdir (Akar, 2013:28).

Doğal afetlerin fiziksel ve sosyal etkileri, ekonomik etkileri doğurmaktadır. Doğal afetler reel ekonomide gelir, yatırım, tüketim, üretim ve istihdam gibi ekonomik faaliyetlerin azalmasına neden olmaktadırlar. Aynı zamanda sermaye ve mal stoklarında kayıplar, kısa vadeli ekonomik işlemlerde azalmalar da meydana gelmektedir. Bu durum uzun vadede ulusal ve küresel ekonominin de zarar görmesine yol açmaktadır (Benson \& Clay, 2003:4).

2000 'li yıllardan itibaren doğal afetlerin etkileri daha fazla hissedilmeye başlamış ve dolayısıyla ekonomik zararları da artmıştır. Tablo 2'de toplam maliyeti en fazla olan sekiz doğal afet yer

1 Ulusal ve uluslararası kuruluşlar tarafından tutulan kayıtlar kendi içerisinde tutarsızlık göstermektedirler. Örneğin, 17 Ağustos 1999 tarihinde Türkiye’de meydana gelen deprem sonrası Deprem Riskinin Araştırılarak Deprem Yönetiminde Alınması Gereken Önlemlerin Belirlenmesi Amacıyla Kurulan Meclis Araştırması Komisyonu bir rapor hazırlamıştır. Raporda yer alan bilgilere göre Bayındırlık ve İskân Bakanlığı ölü sayısını 18.373 kişi olarak tespit etmiştir (TBMM, 2010:49). Aynı raporda bir grup milletvekilinin verdiği önergede ölü sayısı 17.480 kişi olarak belirtilmiştir (TBMM, 2010:4). Afetlerin Epidemiyolojisi Araştırma Merkezi (CRED) ise ölü sayısını 17. 127 kişi olarak kayıtlara geçirmiştir (EM-DAT, 2015b). 
almaktadır ve bu afetlerin hepsi 2000 yılından sonra meydana gelmiştir. Bu doğal afetler, bölgesel açıdan değerlendirildiğinde $\mathrm{ABD}$ ve Asya ülkelerinde meydana geldikleri ve afetlerin deprem ve tropikal kasırga kökenli oldukları görülmektedir. Günümüze kadar meydana gelmiş doğal afetler içerisinde toplam maliyeti en fazla olan doğal afet, 2011 yılında Japonyada meydana gelen depremdir ve yol açtı̆̆ı toplam ekonomik zarar 210 milyar dolardır.

Tablo 2. 2000-20I4 Arasında Toplam Ekonomik Maliyet Bazında En Büyük Doğal Afetler

\begin{tabular}{cccc}
\hline Yll & Doğal Afet Türü & Ülke & Toplam Maliyet (1000\$) \\
\hline $11.3 .2011-11.3 .2011$ & Deprem-Tsunami & Japonya & 210.000 .000 \\
$29.8 .2005-19.9 .2005$ & Tropikal Kasırga & ABD & 125.000 .000 \\
$12.5 .2008-12.5 .2008$ & Deprem & Çin & 85.000 .000 \\
$28.10 .2012-28.10 .2012$ & Tropikal Kasırga & ABD & 50.000 .000 \\
$5.8 .2011-4.1 .2012$ & Sel & Tayland & 40.000 .000 \\
$27.2 .2010-27.2 .2010$ & Deprem & Şili & 30.000 .000 \\
$12.9 .2008-16.9 .2008$ & Tropikal Kasırga & ABD & 30.000 .000 \\
$23.10 .2004-25.10 .2004$ & Deprem & Japonya & 28.000 .000 \\
\hline
\end{tabular}

Kaynak: (EM-DAT, 2014b).

Doğal afetlerin neden olduğu olumsuz etkilerden birisi de kamu bütçeleri ve borçları açısından karşımıza çıkmaktadır. Genellikle ekonomik faaliyetlerde olduğu gibi kamu gelirleri azalmakta; acil yardımlar ve yeniden yapılanma dolayısıyla da kamu harcamaları artmaktadır (Laframboise \& Loko, 2012:9). Diğer taraftan afetler ulusal ekonomiye göre görece daha küçük ise vergi oranlarında yapılacak artış ile vergi gelirleri artabilir; fakat afetler ulusal ekonomiden görece daha büyük ise vergi gelirlerindeki artış da daha az olacak ve hükümetler dış borçlanma ya da monetizasyon yollarına başvurabilir (Freeman, vd., 2003:11-13). Bununla birlikte kamu bankalarının görev zararları, yerel yönetimlerin harcamaları ve sosyal fonlardan aktarılan kaynaklar da afetlerin mali etkileridir (Aktürk \& Albeni, 2002:9).

Doğal afetler, fiziki, sosyal ve ekonomik açıdan olduğu kadar çevresel açıdan da yeryüzünü ve insanları etkilemektedir. Doğal afetler ekosistemde ciddi zararlara yol açmakta; tarıma elverişli arazileri ve ormanları yok etmektedir (Hochrainer, 2006:21). Doğal afetlerin olumsuz etkilerinin yanında sellerin ağaçları yenilemesi gibi çevreye olumlu etkileri de mevcuttur (Akar, 2013:48). 


\section{Doğal Afetlerin Finansmanı}

\section{Doğal Afetlere Yönelik Kamu Politikaları}

Hükümetlerin doğal afetlerin olumsuz etkilerini tamamen ortadan kaldırmaları mümkün değildir. Dolayısıyla hükümetler olumsuz etkileri minimuma indirmeye çalışarak ve yeniden yapılanmayı hızlandırarak afet sürecini yönetmelidirler. Doğal afet yönetimi; afet öncesinde, esnasında ve sonrasında ihtiyaç duyulan tüm çalışmaları kapsamaktadır. Şekil 1'de yer alan ve kurumsal, politik, normatif ve mali açıdan değerlendirilen afet risk yönetimi; risk tanımlama, risk azaltma, mali koruma, afete hazırlık ve afet sonrası yapılanma faaliyetlerini kapsamaktadır.



Şekil I. Kapsamlı Afet Risk Yönetim Stratejisi

Kaynak: (Ghesquiere \& Mahul, 2010:6).

Doğal afetlerin etkilerini azaltmak, yönetmek ve engellemek için geliştirilmiş politika ve uygulamaları kapsayan bir kavram olan afet yönetimi dört temel aşamadan oluşmaktadır. Bu aşamalar şu şekildedir: Hazırlı; afetlere karşı etkili mücadeleyi kolaylaştırmak için hazırlanmış politika ve prosedürler, tepki; toparlanmayı hızlandırmak, can ve mal güvenliğini sağlamak için afet öncesinde, sırasında ve sonrasında gerçekleşen eylemler, iyileşme; afet öncesi koşullara geri dönmek ve kritik sistemlerin yeniden inşasını sağlamak için afet sonrası gerçekleşen eylemler, azaltım; insanlar ve mallar üzerindeki etkileri azaltmak için afet öncesinde ve sonrasında gerçekleşen eylemler (Henstra \& McBean, 2005:304). 
Hükümetler doğal afetlerle mücadele konusunda hem afet öncesinde (ex ante) hem de sonrasında (ex post) çeşitli stratejiler uygulamaktadırlar. Afet öncesi stratejilerin başında afetin gerçekleşebileceği düşüncesiyle oluşturulan afetle mücadele fonları gelmektedir. Ayrıca hükümetler bina yapım yönetmeliklerinin kapsamı genişletilip imar kısıtlamaları getirerek ya da afetlerin etkilerini azaltan kamu yatırımları yaparak veyahut afet tehlikesi olan bölgelerde afet sigortasını yaygınlaştırarak gelecekte meydana gelecek afetlerin etkilerini azaltmanın yollarını aramaktadırlar. Afet sonrası stratejiler ise, mali kaynakların afetten etkilenmeyen bölgelerden afetten etkilenen bölgelere aktarılmasıdır (Yang, 2008:3).

\section{Doğal Afet Zararlarının Finansmanının Önündeki Engeller}

Etkili bir doğal afet finansmanının önünde dört temel engel bulunmaktadır. Bu engeller; hükümetlerin politik kaygıları, ahlaki tehlike, politikacıların tercihlerindeki zaman uyumsuzluğu ve doğal afetlere yönelik kamu tasarruflarının görünüşteki imkânsızlı̆̆ıdır.

Politik Kaygılar: Hükümetler afet öncesinde gerekli önlemleri almamış olabilir veya afet anında yardım ve kurtarma faaliyetlerinde başarısız olabilirler. Afet öncesi ve sonrasında uygulanan yanlış politikalar, seçimlerde politikacılar açısından olumsuz etkiler meydana getirebilirler. Bir başka değişle afet yönetiminde hükümetlerin başarısız olmaları, oy kaybına neden olabilir. Aynı zamanda afet dönemlerinde insanların hükümet politikalarına karşı tepkileri daha fazla olabilmektedir. Bu yüzden hükümetler afetin yol açtı̆̆ı kayıpları açıklamak istemezler.

Doğal afet dönemleri olağanüstü durumları ifade etmektedir ve bu dönemde yapılan harcamalar bütçe hazırlanırken öngörülememekte, her yıl tekerrür etmemekte ve faydaları da devamlılık göstermektedir (Türk, 2010:68-69). Fakat önceden tahmin edilemeyen harcamaların yapılması gerektiğinde olağanüstü bütçe yerine normal prosedür içinde bütçe çıkarmak da mümkün olup daha uygundur. Ek ödenekler doğal afet yardımlarının ve maliyetlerin karşılanmasında yaygın bir finansman kaynağıdır (Donahue \& Joyce, 2001:735).

Ahlaki Tehlike: Sigorta, afet sonrası durumu iyileştirme ve riskleri yönetme konusunda önemli bir rol oynamaktadır. Çünkü sigorta, çok sayıdaki sigortalı üzerindeki riskleri dağıtarak riski azaltmakta ve afet sonrasında insanların ayakları üzerinde durmasına yardımcı olmaktadır (Hudson, vd., 2014:2). Asimetrik bilgi, ahlaki tehlike ve ters seçim sorunlarına yol açarak piyasanın işleyişini bozabilmektedir. Bu tür sorunlar genellikle sigorta şirketlerine bilgi avantajı sağlamaktadır. Fakat bu tür sorunlar reasürans ${ }^{2}$ (mükerrer sigorta) piyasalarında ortaya çıabilir (OECD, 2012:61).

2 Sigorta edilmiş riskin, belli bir kısmının veya tamamının yeniden sigorta edilmesidir. Sigorta şirketleri, teminat verdikleri rizikolarda büyük hasarların aynı zamana gelme ihtimaline karşı, hasar ödemelerinde zorlanmamak için reasürans (mükerrer sigorta) yaptırır. Reasürans, sigorta şirketlerine, tek başlarına yüklenmeleri kendi sermayeleri, ihtiyatları, özvarlıkları bakımından kısaca mali yönden mümkün olmayan riskleri, sigortalayabilme imkânı verir (Türkiye Sigorta Birliği, 2014). 
Sigorta piyasasının başarısız olması durumunda, sigorta hizmeti ya etkin çalışmamakta ya da yeterli hizmet sunamamaktadır. Özellikle ahlaki tehlike sigorta piyasasının işleyişini bozmakta ve sigorta şirketleri sigorta hizmetlerini sunmada isteksiz davranmaktadır (Akar, 2013:131). Ahlaki tehlike, sigorta satın alan kişinin bu sigortaya güvenerek sigorta yaptırdığı konuya gereken özeni göstermemesidir (Kirmanoğlu, 2013:114). Örneğin, yangına karşı evini sigorta ettiren ev sahibinin yangını önlemede gereken tedbirleri almaması ve daha az dikkatli davranması ahlaki tehlike ile açıklanmaktadır.

Ters seçiş ise sigorta şirketlerinin doğal afet açısından düşük riskli kişiler ile yüksek riskli kişileri ayırt etmesindeki güçlükler nedeniyle ortaya çıkmaktadır. Sigorta piyasasında satıcılar bu bilgiye sahip olmadıkları için, ortalama bir fiyat uygulamakta ve bu fiyat düşük riskli kişiler tarafından yüksek kabul edildiği için bu kişiler piyasadan çekilmektedir. Piyasada sadece yüksek riskli kişiler kalmaktadır (Kirmanoğlu, 2013:114).

Zamansal Tutarsızlık: Afetlere yönelik bütçe politikaları zaman uyumsuzluğuna yol açabildiği için rasyonel seçmenler afet öncesi bütçelere karşı çıkabilirler. Bir başka değişle seçmenler, siyasetçilerin afet öncesi bütçeleri kabul edeceğine inanmaktadır. Siyasetçiler afetlerin yol açtığ zararları karşılamak için vergi oranlarını artırmakta ve elde edilen gelirleri başka amaçlar için kullanabilmektedirler (Phaup \& Kirschner, 2010:7).

11 Mart 2011'de, Japonya’nın Tohoku bölgesinde 9,0 büyüklüğündeki deprem ve sonrasında gerçekleşen tsunami sonucu ortaya çıkan konut sorununa çözüm olarak Japon hükümeti geçici bir program başlatmıştır. Söz konusu program zaman tutarsızlığı problemini ortaya çıkarmış ve aynı zamanda afetlerin önlenmesinde olumsuz etkilere yol açmıştır (Tanaka, 2012:12).

Hükümetler insanların dere yatakları, deprem bölgeleri ve kıyı şeritleri gibi doğal afet riski yüksek olan bölgelere ev ve işyeri yapmamaları konusunda uyarılarda bulunmaktadırlar. Fakat insanlar olağan dönemlerde bu uyarıların çok fazla olmamasının da etkisiyle bu bölgelere yerleşmekte ve afetlerin yaşanmasıyla birlikte zor durumda kalmaktadırlar. Hükümetler ise bu durum karşısında gerekli önlemlerin alınacağını söylemektedirler. Fakat afet döneminin sona ermesinden sonra herhangi bir önlem genelde almamaktadırlar. Bu durumda sorun; yaşanan olaylarla, bu olaylara karşı alınması gerekli tedbirlerin aynı zamana rastlamaması, bir zaman tutarsızlığının yaşanmasıdır (Parasız, 2013).

Doğal Afetlere Yönelik Kamu Tasarruflarının Görünüşteki İmkânsızlğ̆ı: Kamu tasarrufu, kamunun harcanabilir gelirinden cari giderlerin çıkarılması sonucu bulunmaktadır. Cari giderler faydaları süreksiz olup her yıl tekerrür eden mal ve hizmet alımına yönelik giderlerdir. Dolayısıyla kamu tüketimi ile ilgilidirler (Türk, 2010:61). Kamu tasarruflarının yatırımların temelini oluşturması sebebiyle hükümetlerin cari giderleri azaltmaya ve böylece tasarrufları artırmaya yönelik politikalar uygulaması gerekmektedir. Ayrıca merkezi yönetim bütçesi kapsamındaki belirli gelir kalemlerinde yaşanan artış ve azalışlar kamunun harcanabilir gelirini, belirli harcama kalemlerindeki değişiklikler de gerek kamunun harcanabilir gelirini gerekse cari giderleri değiştirmek suretiyle kamu tasarruflarını etkilemektedir (DPT, 2010:1). 
Hükümetlerin sosyal güvenlik ödemeleri, emeklilik maaşları, borç faiz ödemeleri ve savunma harcamaları gibi gelecekte yapması gereken harcamalar vardır. Dolayısılla sadece gelecekte meydana gelmesi muhtemel doğal afetler göz önünde tutularak tasarrufların belirli bir amaca yönlendirilmesi çok mümkün değildir.

\section{Doğal Afet Öncesi Finansal Araçlar}

Doğal afet zararlarının karşılanmasında afet öncesi finansal araçlar önemli bir yer teşkil etmektedir. Afet sonrası finansal araçlar ise afet öncesi araçları destekleyici konumdadırlar. Afet öncesi finansal araçlar etkilerini kısa, orta ve uzun vadede göstermektedirler. Kısa vadede acil bir müdahaleyi; orta vadede iyileştirme ve toparlanmayı; uzun vadede ise yeniden yapılanmayı gerektirmektedir. Afet öncesi finansal araçları; afet rezerv fonu, afet sigortası, afet tahvilleri ve olağanüstü durum kredisi oluşturmaktadır.

\section{Afet Rezerv Fonu}

Afet rezerv fonu, afetler dolayısıyla ortaya çıkan küçük çaplı ve tekrar eden zararları karşılayan afet riski finansman aracıdır. Genellikle yıllık bütçe ödenekleri ile finanse edilmekte ve mali yıl sonunda kalan bakiyeler ya biriktirilmekte ya da zaman aşımına uğramaktadır (Poundrik, 2011:4). Afet rezerv fonunun temel avantajı; afet anında acil olarak kullanılabilecek bir kaynak olmasidir.

Rezerv fonu uygulamalarının en bilineni Meksikadaki FONDEN'dir. FONDEN, doğal afet harcamaları için oluşturulmuş bir yıllık bütçe tertibidir ve kalan bakiyeler bir sonraki yıla aktarılmazken (Kreimer vd., 1999:23); Filipinler'de Ulusal Afet Fonu’nda zaman aşımına uğramaktadır.

Fon uygulamasında hükümetler, bütçenin belli bir oranını veya tutarını bu fona ayırmakta, fonda biriken paralar ise afet tahvili gibi finansman araçlarına yatırılmaktadır. Fona aktarılacak payın belirlenmesinde, afetin toplam maliyetinin yıllık gerçekleşme oranına bölünmesi ile elde edilen miktar belirleyicidir (Akar, 2013:117). Rezerv fonlar acil müdahale, yardım, kurtarma ve yeniden yapılanma gibi çeşitli amaçlar için kullanılmaktadır (OECD, 2013:52). Ayrıca doğal afetlerin türüne göre fon uygulamaları bazı ülkelerde farklılaşmaktadır. Örneğin Endonezya, Malezya ve Filipinler'de tsunaminin yol açtığı zararlara yönelik fon uygulamaları daha yaygındır.

Afet rezerv fonunun oluşturulabilmesinde ülkenin bütçe dengesinin sağlanmış olması veya bütçe fazlası vermesi önemli bir etkendir. Bütçe açığına sahip bir ülkenin fon sıkıntısı çekme ihtimali yüksek olduğu için afet rezerv fonu oluşturması çok doğru olmayabilir.

Rezerv fonlarında önemli miktarda kaynak biriktirmek zaman almaktadır. Ayrıca büyük afetlerden sonra fon tüketilmiş olabilir ve fonda kaynak biriktirmek zaman alabilir. Bu tarz 
risklerle mücadele etmek amacıyla bazı ülkelerde rezerv fonuna kaynak aktarımı yasal olarak güvence altına alınmıştır. Örneğin; Kolombiya’da federal hükümet bütçe gelirlerinin belirli bir kısmını doğal afet rezerv fonuna aktarmakla yükümlüdür ve bu durum yasayla güvence altına alınmıştır (GFDRR, 2011:7).

\section{Afet Sigortası}

Doğal afet, kaza, yangın, hırsızlık, ölüm, kuraklık gibi riskler yüzünden gelecekte ortaya çıkabilecek kayıpları karşılamak amacıyla belli bir prim karşılı̆̆ında satın alınan güvence (TDK, 2014) olarak kavramlaştırılan sigorta benzer risk grubunda bulunan kişilerin maddi güçlerini birleştirerek yardımlaşmasıdır. Diğer deyişle aynı risk grubunda bulunan kişiler bir araya gelerek kişi başına düşen maliyetleri azaltmakta ve büyük riskler dahi kişiler arasında paylaştırılmış olmaktadir.

Doğal afetler nadiren ortaya çıkmaları ve ortaya çıktıklarında da maddi ve manevi olarak büyük yıkımlara sebep olmaları nedeniyle olağan üstü riskler olarak nitelendirilmektedir. Bu durum doğal afetlere yönelik sigorta primlerinin yüksek olmasına yol açmakla birlikte bazı doğal afetlerin de sigorta kapsamı dışında bırakılmasına neden olabilmektedir.

Doğal afetlere karşı sigorta mekanizmasının oluşturulmasının kökenleri özellikle ABD ve Japonya gibi gelişmiş ülkelerde yaşanan doğal afetlerdir. Bu durum doğal tehlikeler karşısında sigortanın önemini ortaya çıkartmış ve afet risk sigortası piyasalarının oluşturulmasına neden olmuştur. Ancak sigorta uygulaması, doğal afetlerin yaratmış olduğu bütçesel baskıların hafifletilmesine yardımcı olması ile bilinmesine rağmen gelişmekte olan ülkelerdeki uygulaması bugüne kadar sinırlı kalmıştır (Hofman \& Brukoff, 2006:4-5).

Afet sigortaları hem özel sektör hem de kamu sektörü tarafından düzenlenmektedir. Büyük ölçekli doğal afetlerin yönetiminde özel sigorta piyasalarının afet risk azaltım faaliyetleri kamu sektörüne göre daha etkindir. Örneğin 1939 yllında İsviçre’de özel sigorta şirketleri devletten doğrudan mali destek almaksızın Doğal Tehlike Havuzu isimli fonu oluşturmuştur. Benzer doğrultuda, Portekizde özel sigorta sektörü deprem riskleri nedeniyle ortaya çıkan zararları karşılamak için bir havuz mekanizması oluşturulmuştur (OECD, 2003:28-29).

Afet sigortasının farklı türleri bulunmaktadır. Bu yöntemlerden bir tanesi risk havuzu oluşturmaktadır. Belirli ülkeler bir araya gelerek bir havuz oluşturmakta ve doğal afete maruz kalan ülke bu havuzdan belirli kurallar dâhilinde faydalanabilmektedir. Havuz sisteminin etkin çalışabilmesi için havuzun olabildiğince büyük ve ülkelerin risk yapısındaki korelasyonun olabildiğince düşük olması gerekmektedir (Hofman \& Brukoff, 2006:17). Bir başka sigorta türü ise mikro sigortadır. Daha çok gelir durumu yetersiz olan ve tarımla uğraşan bireylerin kullandığ 1 sigorta türüdür. 


\section{Afet Tahvili}

Sigorta veya reasürans şirketleri, belli bir prim ödemesi karşılığında sigorta şirketlerinin risklerini transfer etmektedirler. Ancak doğal afetlerin gerçekleşme olasılığı düşük olmakla birlikte yüksek hasar olasılığına sahip olmaları, sigorta veya reasürans şirketleri için tehlike oluşturmaktadır. Bu nedenle 1990’lı yıllarda ABD’de sigorta sektörüne uygun menkul kıymetler geliştirilmiştir. Organize ve organize olmayan (tezgah üstü) piyasalarda opsiyon, swap, future ve tahvil şeklinde işlem gören ve sigorta veya reasürans şirketleri tarafından ihraç edilen bu türev ürünler ve menkul kıymetlerden en yaygın olanı afet tahvilleridir (Carr \& May, 2011:2; Çekici, 2011:58).

Doğal afet tahvillerinde riskler deprem, kasırga, sel gibi doğal afetlerdir. Riskin gerçekleşmesi durumunda sigortalı varlıklarda meydana gelebilecek maddi hasar, tahvil yatırımcısı tarafından karşılanmaktadır. Böylece gerçekleşebilecek büyük hasarlı riskler sermaye piyasasında dağıtılmakta, tahviller etkili birer risk yönetim aracı işlevi görmektedir (Doğan, 2013:13).

Afet tahvillerinde temel nokta, belirtilen afet olayının tanımlanan vadede gerçekleşmemesidir. Eğer belirtilen afet bu süre içinde gerçekleşir ise tahvil sahibi, faiz ödemesini ya da faiz ve anapara ödemesini alamamaktadır. Afetin gerçekleşmemesi durumunda ise vade sonunda faiz ve anapara ödemesi yapılmaktadır (Çekici, 2011:59).

Türkiye'de ilk afet bonosu 2013 yılında DASK tarafından Bermuda'da kurulan Bosphorus 1 Re isimli özel amaçlı şirket tarafından ihraç edilmiştir ve İstanbul'da olası bir deprem riskine karşı, 3 yıl vadeli ihraç edilmiştir. S\&P'den BB+ kredi notunu alan bononun ihraç tutarı başta 100 milyon \$ olarak belirlenmiş, daha sonra 400 milyon \$’a yükseltilmiştir. Portföy, yüksek kredi derecesine sahip ABD hazine para piyasası fonlarında, Munich Re’nin varlık yönetim şirketi olan MEAG tarafından yönetilecek ve varlıkların değerlendirildiği araçların getirisinin \%2.5 üzerinde yıllık getiri sağlayacaktır (Doğan, 2013, s. 21).

\section{Olağanüstü Durum Kredisi}

Dünya Bankası ve Amerika Kıtası Kalkınma Bankası gibi uluslararası kuruluşlar son yıllarda doğal afetlerden etkilenen gelişmekte olan ülkeler için olağanüstü durum kredisi olarak adlandırılan yeni bir araç geliştirmişlerdir (Ghesquiere \& Mahul, 2010:9). Olağanüstü durum kredisi düşük faiz oranları ile borçlanabilme imkânı sağlamaktadır. Başka bir değişle doğal afet esnasında kaynaklara hızlı ve esnek erişim olanağı sunmakta ve hükümetlerin kısa vadede rahat bir nefes almasına yardımcı olmaktadır.

Olağanüstü durum kredisi riskin transfer edilmesi yerine zamana yayılmasıdır. Kredi seçenekleri çoğu zaman alternatif risk transfer araçları altında gruplandırılmaktadır. Böylece olağanüstü durum kredileri doğal afetten önce yıllık küçük idari maliyetlere sahipken afet sonrasında büyük borç servis ödemelerine sahiptir (Hochrainer, 2006:98). 
Olağanüstü durum kredilerine özellikle Hint Okyanusu’nda bulunan ada ülkeleri mali direnç sağlamak amacıyla başvurmaktadırlar. Krediler afet sonrasında hükümetlere ek bir finansman kaynağı olmakla birlikte kredilerin miktarı ülkenin borçlanma kapasitesi ile sınırlandırılmaktadır. Yüksek borç miktarına ve sınırlı borçlanma kapasitesine sahip olan pek çok küçük ada ülkesinde durum böyledir (Ghesquiere \& Mahul, 2010:11). Örneğin; konumu ve topografyası gereği sıklıkla sellere, hortumlara ve toprak kaymalarına maruz kalan Seyşeller olağanüstü durum kredisini kullanan ilk Afrika ülkesidir. 2013 yılında meydana gelen kasirga sonrası 8.4 milyon dolar zarar (ülkenin 2012 yllı GSMH’nin \%0,77’si) oluşmuştur. Hükümetin acil durum kararı aldığı zamanlarda kullanılmak üzere olağanüstü durum kredisi oluşturulmuştur. Kredi 3 yıllıktır ve 15 yllda bir yenilenmektedir (GFDRR, 2014).

\section{Doğal Afet Öncesi Finansal Araçlara İlişkin Ülke Örnekleri}

Çalışmada afetlerin yaygın olarak meydana geldiği ve reform niteliğinde gelişmelerin yaşandığ Meksika, Japonya ve Türkiye, afet öncesi finansal araçların uygulanabilirliği açısından örnek ülkeler olarak seçilmiştir.

\section{Meksika}

Özellikle kasırga, deprem ve sellerin yoğun etkisi altında bulunan Meksika'da 2014 yllına kadar kayda alınmış 238 doğal afet meydana gelmiştir. Bu doğal afetlerde 23.187 kişi yaşamını yitirmiş, 36.819 kişi yaralanmış ve 17.831 .461 kişi ise etkilenmiştir (EM-DAT, 2014c). Meksika’daki en büyük can kaybına neden olan doğal afet ise 1985 yılında meydana gelmiştir. Meksiko City'de 8.1 büyüklüğündeki depremde 6.000 insan hayatını kaybetmiş, 30.000 insan yaralanmış, 150.000 insan etkilenmiş ve 4 milyar dolar mali kayba yol açmıştır. Bu doğal afet sonucu kurulan kurumlardan bir tanesi de FONDEN'dir (Poundrik, 2011:4).

1999 yılında FONDEN federal hükümetin doğal afet sonrası müdahale ve yeniden yapılanmayı sağlamak için kurulmuş bir bütçe programıdır. FONDEN başlangıçta üç farklı fon aracılı̆̆ıyla yıllık olarak fon tahsis eden bir bütçe aracı olarak görev yapmaktaydı. Bu fonlar; i) Sigortasız kamu altyapı hizmetlerine yönelik altyapı fonu, ii) Düşük gelirli çiftçilere yönelik tarım fonu ve iii) Afetzedelere yönelik yardım fonudur (Poundrik, 2011:4). Kurumun birincil amacı olumsuz doğa olaylarına karşı bütçe yönetimini geliştirmektir. Diğer amaçları ise altyapı hizmetlerinin yeniden gözden geçirilmesini, düşük gelirli bireylerin maddi açıdan desteklenmesini ve uygun doğal ortamın yeniden oluşturulmasını sağlamaktır (GFDRR, 2013:1). FONDEN'in gelirleri Federal Harcama Bütçesi’nden sağlanmaktadır. Federal Bütçe Kanunu yıllık federal bütçenin \%0,4’ünden az olmamak üzere belirli miktardaki kaynağın FONDEN’e aktarılmasını gerektirmektedir (GFDRR, 2012:11).

Hükümet 2006 yılında, depremlerin mali sonuçlarını kapsayan işlem değeri yaklaşı olarak 160 milyon dolar olan parametrik bir afet tahvili yayımlamıştır. Meksiko City ya da Pasifik kıyısında 7.5 veya 8.0 büyüklüğündeki bir depremde işlem, hükümete acil finansman kaynağı olacaktır. 
Afet tahvili ABD ve Avrupadaki kurumsal yatırımcilara satılmaktadır ve FONDEN'e fayda sağlayan bir reasürans aracı konumundadır (OECD, 2008:82).

Meksika'da afet rezerv fonu, afet sigortası ve afet tahvilleri doğal afetlere yönelik afet öncesi finansal araçlardır. Olağanüstü durum kredileri ise ulusal bütçe üzerinde baskı oluşturacağı ve Meksika’nın kredi notunu olumsuz etkileyeceği için hükümet tarafından uygulanmamaktadır (Cardenas, vd., 2007:3).

\section{Japonya}

Doğal afetlerden maddi ve manevi anlamda en fazla zarar gören ülkelerden birisi de Japonya'dır. Deprem, sel, heyelan, fırtına ve volkanik patlamalar Japonya'da sıklıkla görülen doğal afetlerdir ve her gün bir doğal afetle karşı karşıya kalınma ihtimali oldukça yüksektir. 2014 yılına kadar Japonyada 317 doğal afet meydana gelmiş, 240.491 kişi yaşamını yitirmiş, 255.690 kişi yaralanmış ve 18.410.518 kişi ise etkilenmiştir. Doğal afetlerin bugüne kadar yol açtığı maddi zarar ise 435.5 milyar dolardır (EM-DAT, 2014c). 1923 Kanto depreminde en fazla can kaybının yaşandığı doğal afettir. Depremde 143.000 kişi yaşamını yitirmiştir. 2011 yılında 9.0 büyüklüğündeki Tohoku depremi ve sonrasında oluşan tsunami sonucu 15.790 kişi hayatını kaybetmiş ve 210 milyar dolar maddi kayıp yaşanmıştır (EM-DAT, 2015b). Tohoku depremi ve tsunamisi Japonya tarihinin en fazla maddi kayba yol açan doğal afetidir. Japon hükümeti 2011 yılında deprem ve tsunaminin etkilerinin telafi edilmesi amacıyla 48,9 milyar dolarlık olağan üstü bütçeyi uygulamaya başlamıştır (BBC, 2011). Söz konusu doğal afetler ile mücadelede afet zararlarının hafifletme ve sigorta uygulamaları olmak üzere iki politika aracı vardır. Her iki araç da tasarrufları artırmakta ve ahlaki tehlikeyi azaltmaktadır.

Japonyada sıklıkla doğal afetlerin meydana gelmesi afetlerle mücadele konusunda yasal düzenlemelerin yapılmasını zorunlu kılmıştır. Konut Kalite Güvencesi Yasası, Güçlendirme Çalışmalarını Teşvik Yasası, Bina Standartları Yasası, Afetle Mücadelede Alınacak Önlemler Kanunu gibi yasal düzenlemeler, Japonya'da binalar doğal afetlere karşı daha dayanıklı yapılmasını ve halkın afetlere karşı zorunlu önlemler almasını sağlamıştır.

Yapılan yasal düzenlemelerin olumlu sonuçlar verdiği kesindir. Bu durum yaşamını yitiren insan ve yıkılan bina sayısından anlaşıldığı gibi ulusal bütçeden doğal afetlerle mücadeleye ayrılan paydada kendisini göstermektedir. 1960'lı yıllarda ulusal bütçenin \%8-9'u doğal afetlerle mücadele için ayrılmaktayken bu oran 2000'li yıllarda \%2-3’lere düşmüştür (Toyama \& Sagara, 2013:4).

1966 yılında deprem sigortasının ülkede yerleşmesini sağlamak adına Japon Deprem Reasürans Şirketi (JER) kurulmuştur. Şirket deprem, tsunami ve volkanik olaylara karşı yerleşim birimlerini korumayı amaçlamaktadır. Kısmen hükümet tarafından finanse edilen sistem, tüm deprem sigorta poliçelerinin yanı sıra olağan üstü durum kredilerinin de toplandığı bir havuz mekanizmasıdır (Chavez-Lopez, 2012:3). Japonyada doğal afetler için sigorta yaptırılması zorunlu değildir. Fakat deprem sigortası ile ilgili olarak yangın sigortası uygulanmaktadır. Konut poliçesi sahipleri yerel sigorta şirketlerinden deprem ve yangın sigortası satın alabilirler. Yangın 
sigortasını satın alan bireyler eğer deprem sigortasını satın almak istemiyorlarsa bireylerin yazılı izin almaları gerekmektedir. Deprem sigortasının zorunlu olmaması sigorta yaptıran birey sayısını azaltmaktadır (OECD, 2008:77). 1992 yılında deprem sigortası yaptıranların oranı \%7 iken; bu oran 2007'de \%20'ye; 2010'da ise \%25'e yükselmiştir (OECD, 2008:125).

Deprem sigorta sistemi kamu ve özel sektörün ortaklığında deprem başına düşen maksimum ödeme miktarını belirlemektedir. Maksimum ödeme miktarı 2014 yılında 6.2 trilyon yendir (Japan Credit Rating Agency, 2014). Deprem sigortasının kapsamını konutlar ve kişisel mülkiyet oluşturmaktadır. Sigorta dönemi kısa vadede 1 yıl, uzun vadede 2 yıldan 5 yıla kadardır. Deprem sigortasının miktarının, yangın sigortasının \%30-50 aralığında olması gerekmektedir. Fakat sigorta miktarı konutlarda maksimum 50 milyon yen; kişisel mülkiyetlerde ise 10 milyon yen ile sinırlidır (Japan Earthquake Reinsurance Co., 2014:14).

Toplam sigorta miktarının sınırı deprem başına ödenecek miktar olarak önceden belirlenmektedir ve 7 trilyon yendir. Bu sistem, sigorta ödemelerinin sorunsuz yapılması şeklinde tasarlanmıştır ve Japon Deprem Reasürans Şirketi, yaşam-dışı sigorta şirketleri ve hükümetin payını gösteren reasürans şemasıdır. Şemanın 2014 yılı itibariyle işleyişi şu şekildedir: JER, deprem başına 100 milyar yene kadar olan hasarları sigorta kapsamında ödemektedir (birinci dilim). Hükümet ve diğerleri (JER ve yaşam-dışı sigorta şirketleri) 100 milyar yeni aşan ve 362 milyar yenin altındaki hasarların sigortasını eşit şekilde bölüşürler (ikinci dilim). 362 milyar yeni aşan hasarların sigortasının \%99,5’i hükümet tarafından ödenmektedir (üçüncü dilim) (Japan Earthquake Reinsurance Co., 2014:22).

Tablo 3. Japonya'da Kurumların Sorumluluk Sınırları, (2014)

\begin{tabular}{ccc}
\hline Sigorta Yapan Kurum & Tutar (Milyar Yen) & \% \\
\hline Japon Deprem Reasürans Şirketi & 224.7 & 3 \\
Yaşam-Dışı Sigorta Şirketleri & 36.7 & 1 \\
Hükümet & $6,738.6$ & 96 \\
Toplam & $\mathbf{7 . 0 0 0}$ & $\mathbf{9 1 0 0}$ \\
\hline
\end{tabular}

Kaynak: (Japan Earthquake Reinsurance Co., 2014:22).

Tablo 3’te 2014 yllı itibariyle üç dilim sonucunda sigorta ödemelerinin hükümet, JER ve yaşamboyu sigorta şirketleri arasındaki dağılımı gösterilmiştir. Toplamda en fazla ödeme hükümet tarafından yapılmaktadır. Hükümet tarafından yapılan ödeme, toplam ödemelerin \%96’sıdır.

Japonyàda doğal afetlerle mücadelede tüm afet öncesi finansal araçlar kullanılmaktadır. Daha çok da afet sigortaları yaygın olarak kullanılmaktadır. 2011 yılındaki deprem ve tsunami afet tahvillerinin çok da etkin bir finansal araç olmadığını göstermektedir. 


\section{Türkiye}

Özellikle deprem ve sellere maruz kalan Türkiye’de 2014 yılına kadar kayıt alına alınan 159 doğal afet meydana gelmiştir. Bu doğal afetlerde 92.106 kişi yaşamını yitirmiş, 98.676 kişi yaralanmış, 7.551.297 kişi de etkilenmiştir (EM-DAT, 2015a). Türkiye'de en fazla can ve mal kaybına neden olan doğal afetler depremlerdir. Kayıt altına alınmış olan can kaybının en fazla olduğu doğal afet 1939 Erzincan Depremi'dir ve 32.962 kişi; 1999 Gölcük Depremi’nde ise 17.127 kişi hayatını kaybetmiş ve 20 milyar dolar maddi kayıp meydana gelmiştir (EM-DAT, 2015b). Yakın geçmişte Türkiye'de Gölcük depreminden yaklaşık üç ay sonra Düzce depremi yaşanmıştır. Ayrıca 2011 yılındaki Van depremleri de maddi ve manevi anlamda büyük hasara yol açmıştır.

1999 yılındaki Gölcük ve Düzce depremleri sonrası doğal afet öncesi bütçe programları konusunda ciddi adımlar atılmıştır. 27 Eylül 2000 tarihinde zorunlu deprem sigortası adı altında ilk bütçe programı uygulamaya konulmuştur. Zorunlu deprem sigortasına göre meskenler için deprem sigortası zorunlu hale getirilmiştir.

Zorunlu deprem sigortası devlet tarafindan sunulan bir güvencedir. Konutları depreme ve depremin doğrudan neden olduğu yangın, infilak, yer kayması ve tsunami gibi afetlere karşı güvence altına almaktadır (DASK, 2014). Zorunlu deprem sigortası, belediye sınırları içinde kalan meskenlere yönelik sigorta sistemidir (Hazine Müsteşarlığı, 2003). Zorunlu deprem sigortası yaptırmayanlar depreme maruz kalmaları durumunda herhangi bir yardım alamamaktadır. Fakat sigorta yaptıranların hasarları sigorta şirketi tarafından karşılanmaktadır.

Zorunlu deprem sigortasının uygulanabilirliğini takip etmek amacıyla Doğal Afet Sigortaları Kurumu (DASK) oluşturulmuş ve kurumun başlangıç sermayesinde Dünya Bankasından olağanüstü durum kredisi kullanılmıştır. Kamu-özel sigorta ortaklığı örneği olan DASK’ın temel amaçları (DASK, 2011:10);

- Kapsamdaki bütün konutları ödenebilir bir prim karşılığında depreme karşı sigorta güvencesi altına almak,

- Kamu bütçesinden bağımsız hızlı çalışan bir ödeme kapasitesi oluşturmak,

- Yurt içinde risk paylaşımını sağlamak, aynı zamanda deprem hasarlarının neden olacağı mali yükü sigorta yoluyla uluslar arası reasürans ve sermaye piyasalarına dağıtmak,

- Deprem hasarlarının telafisi için gerekli uzun vadeli kaynak birikimini sağlamak,

- Toplumda sigorta bilincinin yerleşmesine katkıda bulunmaktır.

Zorunlu deprem sigortası poliçesinin süresi bir yıldır ve poliçe süresi bittiğinde yeniden bir yıl için sigorta yaptırmak zorunludur. Sigorta primi deprem riski yüksek bölgelerde daha çok, deprem riski düşük bölgelerde ise daha az olacak şekilde farklılaştırılmıştır (Gökçe \& Tetik, 2012:67). Türkiyede Ocak 2015 itibariyle toplam 17.661.690 konut bulunmaktadır ve bu konutların 
6.873.130'u sigortalıdır. Dolayısıyla toplam konutların \%38,90'ı sigorta kapsamındadır (DASK, 2015b).

Sigorta için ödenecek prim tutarı Zorunlu Deprem Sigortası Tarife ve Talimatı ile belirlenmektedir. Prim tutarını hesaplamak için öncelikle deprem sonrasında alabilecek en yüksek limiti belirleyen sigorta bedeli (teminat tutarı) bulunmalıdır. Teminat tutarı, tarife fiyatı ile çarpıldığında prim tutarı ortaya çıkmaktadır. 5 risk bölgesi ve 3 farklı yapı tarzına göre belirlenmiş 15 tarife fiyatı vardir (DASK, 2015c).

Poliçe sahiplerinden toplanan paralar ortak bir havuzda toplanmakta ve deprem sonrası sigortalı konutların hasarlarının telafisi için kullanılmaktadır. Sigorta sahiplerinin DASK’a başvurusu sonucu eksperler tarafından hasar tespiti yapılmaktadır. Tespitler sonucu saptanan hasar ödemeleri DASK tarafından konut sahiplerine ödenmektedir. Türkiye'de 2000-2014 yılları arasında 1.545 hasar kaydı için 160.075.047 TL tazminat ödemesi yapılmıştır (DASK, 2015a). Deprem nedeniyle ortaya çıkan zararlar devlet bütçesinden karşılanmak yerine ortak havuzdan telafi edilmektedir.

DASK her yıl inşaat maliyetlerindeki artışa göre belirlediği azami bir tutarda teminat sağlamaktadır. DASK tarafından verilen azami teminat tutarı, 1 Ocak 2013 tarihinden itibaren bütün yapı tiplerinde 150 Bin TL'dir. Azami teminat tutarı tespit edilirken, yıkılan meskenin yeniden inşa edilmesinin maliyeti (arsa değeri hariç) dikkate alınmaktadır. Sigortalının teminat tutarı (sigorta bedeli) -azami teminat tutarını geçmemesi koşuluyla- meskenlerinin büyüklüğüne ve yapı tarzına göre belirlenmektedir. Eğer meskenin değeri DASK tarafından verilen azami teminat tutarını aşıyorsa, sigortalı isteğe bağlı olarak, aşan kısım için sigorta şirketlerinden ek teminat alabilirler. Bunun için özel sigorta şirketlerinden konut sigortasının olması gereklidir (DASK, 2015d).

\section{Sonuç}

Deprem, kasırga, sel ve tsunami gibi doğal afetler özellikle son yüzyılda daha sık meydana gelmektedir ve insanların can ve mal güvenliğini ciddi şekilde etkilemektedir. Doğal afetlerin her birisinin fiziksel, sosyolojik ve ekonomik açıdan toplum yaşamını etkilediği görülmektedir. Söz konusu etkiler sürekli artış halindedir. Doğal afetlerin sayısının artmasına paralel olarak ölü, yaralı, etkilenen insan sayısında ve maddi hasarda da artış meydana gelmiştir. Fiziksel açıdan binaların, altyapının ve malların zarara uğramasına neden olan doğal afetler sosyolojik açıdan toplumun huzurunun ve bireylerin psikolojisinin bozulmasına; ekonomik açıdan ise kalkınmanın ve büyümenin azalmasına, bütçe açıklarının artmasına neden olduğu gözlenmektedir.

Hükümetler doğal afetlerin söz konusu olumsuz etkilerini tamamen ortadan kaldırmak adına düzenli politikalar uygulamaktadırlar. Fakat hükümetlerin olumsuz etkileri tamamen ortadan kaldırmaları mümkün olmamakla birlikte hükümetler, olumsuz etkileri minimuma indirerek 
ve yeniden yapılanmayı hızlandırarak afet sürecini yönetebilirler. Hükümetler afet öncesinde, sırasında ve sonrasında doğal afetlerin etkilerini azaltmada çeşitli finansal araçlar kullanılmaktadır. Çalışmada afet öncesi finansal araçlar incelenmiştir. Bu araçlar; afet rezerv fonu, afet sigortası, afet tahvilleri ve olağanüstü durum kredisidir. Söz konusu araçlar pek çok ülkede afet öncesi mali kaynak sağlamak amacıyla kullanıldığı görülmektedir. Bu araçlardan en yaygın kullanılanı ve en başarılı sonuçlar vereni afet sigortasıdır ve doğal afetlerin sıklıkla yaşandı̆̆ı tüm ülkelerde (Japonya, Yeni Zelanda, ABD, Avustralya) başvurulan birincil afet öncesi finansal araç olmuştur.

Afet öncesi finansal araçlar ve kurumlar bakımından pek çok ülke Meksika, Japonya ve Türkiye'yi örnek almaktadır. Meksika'da söz konusu finansal araçlardan afet rezerv fonu, afet sigortası ve afet tahvillerinin temel araç olarak kullanıldığı tespit edilmişken; olağanüstü durum kredilerinin ulusal bütçe üzerinde baskı oluşturacağı ve Meksika’nın kredi notunu olumsuz etkileyeceği düşüncesiyle hükümet tarafından kullanılmadığı görülmektedir. Japonya'da ise başta afet sigortası olmak üzere tüm afet öncesi finansal araçlar kullanılmakla birlikte 2011 depremi afet tahvillerinin başarılı olmadığını göstermiştir. Deprem sigortasının zorunlu olmaması sigortalı konut sayısını olumsuz yönde etkilemiştir. 2010 yılında deprem sigortası yaptıranların sayısı toplam halkın \%25'idir. Türkiye'de ise özellikle afet sigortası birincil araçtır ve deprem sigortası yaptırmak zorunludur. Deprem sigortası zorunlu olmasına rağmen sigortalı konut sayısı (toplam konutların \%38,9) oldukça düşüktür. Diğer finansal araçların ise Türkiye açısından oldukça yeni araçlar olduğu tespit edilmiştir. Ayrıca afet öncesi finansal araçların gelişmiş ülkelerde daha etkin kullanıldığı; gelişmekte olan ve az gelişmiş ülkelerde ise ya hiç kullanılmadığ ya da kullanımının çok sınırlı olduğu görülmektedir.

Günümüzde her an bir doğal afetin yaşanması kaçınılmaz hale gelmiştir. Ne zaman ve nerede meydana geleceği belli olmayan bu doğa olaylarının olumsuz etkilerinin en aza indirmek için hükümetler eğitimler, seminerler ve konferanslar düzenleyerek halkı bilinçlendirmeli, yapı denetimlerini daha sık ve düzenli yapmalı, afet sigortası daha yaygın hale getirilmeli ya da zorunlu kılınmalı ve diğer finansal araçların kullanımı yaygınlaştırılmalıdır. 


\section{Kaynakça}

Akar, S. (2013) Doğal Afetlerin Kamu Maliyesi Üzerine Etkisi: Türkiye Örneği, Marmara Üniversitesi, Sosyal Bilimler Enstitüsü, Maliye Anabilim Dalı, İstanbul.

Aktürk, İ., M. Albeni (2002) “Doğal Afetlerin Ekonomik Performans Üzerine Etkisi: 1999 Yllında Türkiye’de Meydana Gelen Depremler ve Etkileri”, Süleyman Demirel Üniversitesi İktisadi ve İdari Bilimler Fakültesi Dergisi, 7(1), 1-18.

BBC (2011) Japan Government Announces Disaster Relief Budget [Çevrimiçi], http://www.bbc.co.uk/news/ business-13167014, [Erişim: 19.01.2015].

Benson, C., E. Clay (2003) Economic and Financial Impacts of Natural Disasters: An Assessment of Their Effects and Options for Mitigation: Synthesis Report (Vol. Final Report), London.

Cardenas, V., S. Hochrainer, R. Mechler, G. Pflug, J. Linnerooth-Bayer (2007) “Sovereign Financial Disaster Risk Management: The Case Of Mexico", Environmental Hazards.

Carr, T., A. May (2011) Focus on Alternatives: Catastrophe Bonds Explained.

Chavez-Lopez, G. (2012) "Government Insurance Risk Pool: A Lifesaver or Learning to Swim?", communication presented at the 15th World Conference on Earthquake Engineering, Lisbon.

Çekici, E. (2011) “Doğal Afetler Ve Türk Sigorta Sektöründe Risk Transferi”, Öneri Dergisi, 9(36), 53-62.

DASK (2011) Doğal Afet Sigortaları Kurumu Zorunlu Deprem Sigortası Faaliyet Raporu 2011.

DASK (2014) 9 Adımda Zorunlu Deprem Sigortası [Çevrimiçi], http://www.dask.gov.tr/toplumsal-paylasim9-adimda-zds.html, [Erişim: 19.01.2015].

DASK (2015a) Tazminat Ödemeleri [Çevrimiçi], http://www.dask.gov.tr/zorunlu-deprem-sigortasiistatistikler-3.html, [Erişim: 20. 01.2015].

DASK (2015b) Yürürlükteki Poliçeler [Çevrimiçi], http://www.dask.gov.tr/zorunlu-deprem-sigortasiistatistikler-2.html, [Erişim: 20.01.2015].

DASK (2015c) Zorunlu Deprem Sigortası Tarife ve Primler [Çevrimiçi], http://www.dask.gov.tr/zorunludeprem-sigortasi-tarife-ve-primler.html, [Erişim: 20.01.2015].

DASK (2015d) Zorunlu Deprem Sigortası Teminat ve Kapsamı [Çevrimiçi], http://www.dask.gov.tr/zorunludeprem-sigortasi-teminat-ve-kapsami.html, [Erişim: 20.01.2015].

Doğan, O. (2013) “Doğal Afet Bonoları”, Sermaye Piyasasinda Gündem, 133(Eylül), 12-22.

Donahue, A. K., P. G. Joyce (2001) "A Framework for Analyzing Emergency Management with an Application to Federal Budgeting", Public Administration Review, 61(6), 728-740.

DPT (2010) 1975-2009 Yllları Arasında Kamu Tasarruflarının Gelişimi ve Merkezi Yönetim Bütçesi.

EM-DAT (2014a) Criteria and Definition. Explanatory Notes, [Çevrimiçi], http://www.emdat.be/criteriaand-definition, [Erişim: 18.10.2014].

EM-DAT (2014b) Disaster List, [Çevrimiçi], http://www.emdat.be/disaster_list/index.html , [Erişim: 25.10.2014].

EM-DAT (2014c) EM-DAT Database Advansed Search, [Çevrimiçi], http://www.emdat.be/advanced_ search/index.html, [Erişim: 19.10.2014].

EM-DAT (2015a) EM-DAT Database Advansed Search, [Çevrimiçi], http://www.emdat.be/advanced_ search/index.html, [Erişim: 19.01.2015].

EM-DAT (2015b) Result for Country Profile, [Çevrimiçi], http://www.emdat.be/result-country-profile, [Erişim: 19.01.2015].

Freeman, P. K., M. Keen, M. Mani (2003) Dealing with Increased Risk of Natural Disasters: Challenges and Options, no.3.

GFDRR (2011) Sovereign Disaster Risk Financing, [Çevrimiçi], https://www.gfdrr.org/sites/gfdrr.org/files/ documents/DRFI_Training_SDRF.pdf. 
GFDRR (2012) FONDEN: Mexico's Natural Disaster Fund-A Review vol. may, Washington DC.

GFDRR (2013) FONDEN: Mexico's National Disaster Fund, vol. January.

GFDRR (2014) Seychelles Becomes First African Country to Use Contingent Credit for Disasters.

Ghesquiere, F., O. Mahul (2010) Financial Protection of the State against Natural Disasters, no. 5429, The World Bank.

Gökçe, O., Ç. Tetik (2012) Teoride ve Pratikte Afet Sonrası İyileştirme Çalışmaları, Ankara: T.C. Başbakanlık Afet ve Acil Durum Yönetimi Başkanlığı.

Hazine Müsteşarlığı (2003) Zorunlu Deprem Sigortası hk, [Çevrimiçi], https://www.alomaliye.com/hazine_ zorunlu_deprem.htm, [Erişim: 20.01.2015].

Henstra, D., G. McBean (2005) “Canadian Disaster Management Policy: Moving Toward a Paradigm Shift?” Canadian Public Policy/Analyse de Politiques, 31(3), 303-318.

Hochrainer, S. (2006) Macroeconomic Risk Management against Natural Disasters, Frankfurt: Deutscher Universitats-Verlag.

Hofman, D., P. Brukoff (2006) Insuring Public Finances against Natural Disasters-A Survey of Options and Recent Initiatives, no.6.

Hudson, P., W. J. W. Botzen, J. Czajkowski, H. Kreibich (2014) Risk Selection and Moral Hazard in Natural Disaster Insurance Markets: Empirical Evidence from Germany and the United States, no. 7, Philadelphia.

Japan Credit Rating Agency (2014) JCR Affirmed AAp/Stable Rating on Japan Earthquake Reinsurance, [Çevrimiçi], http://www.jcr.co.jp/release/pdfen/13d09431JEen. pdf?PHPSESSID=3e7d105e379b98b0afbe79722ea654cf.

Japan Earthquake Reinsurance Co. Ltd. (2014) Introduction to Eartquake Reinsurance in Japan Annual Report 2014, Japan Earthquake Reinsurance Co. Ltd.

Keller, E. A., D. E. DeVecchio (2012) Natural Hazards (third edi.). New Jersey: Pearson Prentice Hall.

Kirmanoğlu, H. (2013) Kamu Ekonomisi Analizi (4. Baskı), İstanbul: Beta Yayınları.

Kreimer, A., M. Arnold, C. Barham, P. Freeman, R. Gilbert, F. Krimgold, T. Vogt (1999) Managing Disaster Risk in Mexico: Market Incentives for Mitigation Investment, Washington, D.C.: World Bank.

Laframboise, N., B. Loko (2012) Natural Disasters: Mitigating Impact, Managing Risks, no.12.

Lindell, M. K. (2013) "Recovery and Reconstruction After Disaster" in P. T. Bobrowsky (ed.), Encyclopedia of Natural Hazards, Dordrecht: Springer Netherlands, p.812-824.

Lindell, M. K., C. S. Prater (2003) “Assessing Community Impacts of Natural Disasters”, Natural Hazards Review, 4(4), 176-185.

Middelmann, M. H. (2007) Natural Hazards in Australia. Identifying Risk Analysis Requirements, Canberra: Geoscience Australia.

OECD (1994) Guidelines on Disaster Mitigation, [Çevrimiçi], http://www.oecd.org/dac/environmentdevelopment/1887740.pdf.

OECD (2003) Policy Issues in Insurance Financial Management of Large-Scale Catastrophes, no.12.

OECD (2008) Financial Management of Large-Scale Catastrophes no.12.

OECD (2012) G20/OECD Methodological Framework for Disaster Risk Assessment and Risk Financing, Mexico.

OECD (2013) Disaster Risk Financing in APEC Economies Practices and Challenges.

Parasız, İ. (2013) “Zaman Tutarsızlığı Sorunu”, Ekohaber. [Çevrimiçi], http://www.ekohaber.com.tr/Zaman_ tutarsizligi_sorunu-ekohaber-5-haberid-6602.html, [24.11.2014].

Phaup, M., C. Kirschner (2010) “Budgeting for Disasters: Focusing on the Good Times”, OECD Journal on Budgeting, no.1. 
Poundrik, S. (2011) Disaster Risk Financing: Case Studies, no. 60456.

Tanaka, S. (2012) A Sustainable Public Procurement System for Large-Scale Natural Disasters: The Case of the Temporary Housing Program After the East Japan Earthquake, no. 45, Kobe: Japan.

TBMM (2010) Deprem Riskinin Araştırılarak Deprem Yönetiminde Alınması Gereken Önlemlerin Belirlenmesi Amacıyla Kurulan Meclis Araştırması Komisyonu Raporu (23. Dönem), TBMM.

TDK (2014) Sigorta [Çevrimiçi], http://www.tdk.gov.tr/index.php?option=com_ bts\&arama=kelime\&guid=TDK.GTS.54a19e6c3df533.06467912, [Erişim: 27.11.2014] .

Toyama, M., J. Sagara (2013) Measuring the Cost-effectiveness of Various DRM Measures.

Türk, İ. (2010) Kamu Maliyesi (8.Bas1), Ankara: Turhan Kitabevi.

Türkiye Sigorta Birliği (2014) Reasürans [Çevrimiçi], http://www.tsb.org.tr/reasurans.aspx?pageID=440, [Erişim: 17.11.2014].

Yang, D. (2008) "Coping with Disaster: The Impact of Hurricanes on International Financial Flows, 19702002”, The B.E. Journal of Economic Analysis \& Policy, 8(1). 